\title{
FIRST LARVAL RECORD OF Lipiniella moderata Kalugina, 1970 IN TURKISH INLAND WATERS
}

\author{
Nurcan ÖZKAN \\ Trakya University, Faculty Education, Department of Science Education, 22030, Edirne, TURKEY \\ e-mail: nurcanozkan@ hotmail.com \\ Cite this article as: \\ Özkan N. 2018. First Larval Record of Lipiniella moderata Kalugina, 1970 in Turkish Inland Waters. Trakya Univ J Nat Sci, 19(1): 59-62, DOI: \\ 10.23902/trkjnat.337274
}

Received: 08 September 2017, Accepted: 20 March 2018, Online First: 22 March 2018, Published: 15 April 2018

\begin{abstract}
In this study, Lipiniella moderata Kalugina, 1970 (Diptera, Chironomidae) is reported for the first time in larval form from the part of Tunca River in Edirne, Turkey. The larvae were collected from three different sampling stations along the river. One of the stations was selected in the river segment passing next to Edirne city center and the other two stations were selected in Suakacağı and Değirmenyeni villages located to the north of city center. A total of 145 L. moderata from the stations were sampled from June to October 2012. The highest number of larvae $(n=89)$ were determined in the station in Edirne city center in August. Some morphological characters of the larvae and the sampling habitat characteristics are given, and they are discussed in terms of the biogeographical distribution of the species.
\end{abstract}

Key words: Chironomidae, Lipiniella moderata, first record, Tunca River, Turkey.

Özet: Bu çalışmada Lipiniella moderata Kalugina, 1970 (Diptera, Chironomidae) Tunca Nehri (Edirne, Türkiye)'nden ilk kayıt olarak bildirilmiştir. Larvalar nehir boyunca üç farklı örnekleme istasyonundan toplanmıştır. İstasyonlardan bir tanesi nehrin Edirne şehir merkezi yanından geçen bölümünden, diğer iki istasyon ise şehir merkezinin kuzeyinde yer alan Suakacağı ve Değirmenyeni Köyleri'nden seçilmiştir. İstasyonlardan Haziran - Ekim 2012 döneminde toplam 145 adet L. moderata larvası örneklenmiştir. En fazla larva (n=89), Ağustos ayında Edirne il merkezindeki istasyonda tespit edilmiştir. Larvaların bazı morfolojik ve habitat özellikleri verilmiş ve biyocoğrafik dağılım yönünden tartışılmıştır.

\section{Introduction}

Chironomidae is a taxonomically diverse group with representatives from nine subfamilies (Telmatogetoninae, Orthocladiinae, Chironominae, Tanypodinae, Diamesinae, Podonominae, Prodiamesinae, Buchonomyiinae and Aphroteniinae) and includes species adapted a life style in intertidal zones of coasts all over the world. Lipiniella Shilova, 1961 is a Holarctic genus within the tribe Chironomini from the subfamily Chironominae and is widely distributed in Europe (Ashe et al. 1987, Klukowska et al. 2011, Orendt \& Faasch 2011, Sæther \& Spies 2011).

The genus is represented in Europe with three species; Lipiniella araenicola Shilova, 1961, L. moderata Kalugina, 1970, and L. prima Shilova, Kerkis \& Kiknadze, 1993, among which $L$. araenicola has the widest distributional range covering 10 countries [Belarus, Czech Republic, Finland, France, Germany, The Netherlands, Norway, East Palaearctic, Russia (Central, East, North, South) and Slovakia] (Hamerlik 2006). L. araenicola is associated with stagnant waters with sandy substratum, while the other two species inhabit large rivers (Shilova et al. 1992, Moller Pillot 2009, Orendt \&
Faasch 2011). L. prima has been recorded so far only from Finland and Russia while L. moderata has been reported from Belarus, France, Germany, Hungary, The Netherlands, Norway, Poland, Serbia and the Far East Russia (Shilova et al. 1992, Sæther \& Spies 2011).

Lipiniella moderata was recorded from nearly all surrounding countries of Turkey except Kaliningrad Region of Russian Federation (Sæther \& Spies 2011, Bitušík et al. 2006, Hamerlík 2006). It was first recorded in Russia in riparian sand of a fish pool near the shore of the River Oki near Serpuchova (Kalugina 1970). In central and western parts of Europe, the species was recorded from the rivers Vistula and Bug in Poland (Klukowska et al. 2011), from the potamal reaches of rivers in Hungary (Móra 2008), Czech Republic (Biró 2000), France (Laville \& Serratosio 1996), the Netherlands and Germany (Orendt \& Faasch 2011). The first record of $L$. moderata presented the present study come from habitats typical for this species - mainly sand bottom with silt or gravel and rocks. Sandy substrate is characteristic for the bottom of most of the large Polish lowland rivers (Moller Pillot 2009). 
Lipiniella has previously been reported in Turkey from Kiremitlik stream in Çokal village, Gelibolu, Çanakkale (Özkan 2007) but the material was identified at genus level. This present study reports L. moderata for the first time in Turkey.

\section{Materials and Methods}

Tunca River originates in the Yumurkçal hill in MiddleBalkans in Bulgaria and merges with Meriç River in Edirne-Turkey as its main branch after running for $350 \mathrm{~km}$. It enters Turkey in Suakacağı village, which is one of the stations included in the present study (see below), runs for $30 \mathrm{~km}$ in Turkey and $12 \mathrm{~km}$ part of this $30 \mathrm{~km}$ segment forms the border between Turkey and Bulgaria.

The study material was collected from three stations along the river (Fig. 1). Sampling was performed in monthly intervals from June to October 2012. The larvae were collected from benthos with a hand-net. The riverbed width in the sampled parts of the river was approximately $15 \mathrm{~m}$ for each station and its depth ranged from 25 to $125 \mathrm{~cm}$. The river had a continuous water flow during samplings.

The material collected was placed in plastic bottles containing $70 \%$ ethyl alcohol, labelled and transferred to the laboratory. Chironomid larvae were cleaned under a binocular microscope (Olympus SZ61) and separated from other groups. Temporary and permanent preparations were done, and the material was identified using the keys of Shilova et al. (1992), Makarchenko \& Makarchenko (1999), Klink \& Moller Pillot (2003), Kobayashi et al. (2007), Moller Pillot (2009), Orendt \& Spies (2010) and Klukowska et al. (2011). The study material is deposited in the personal collections of the author.

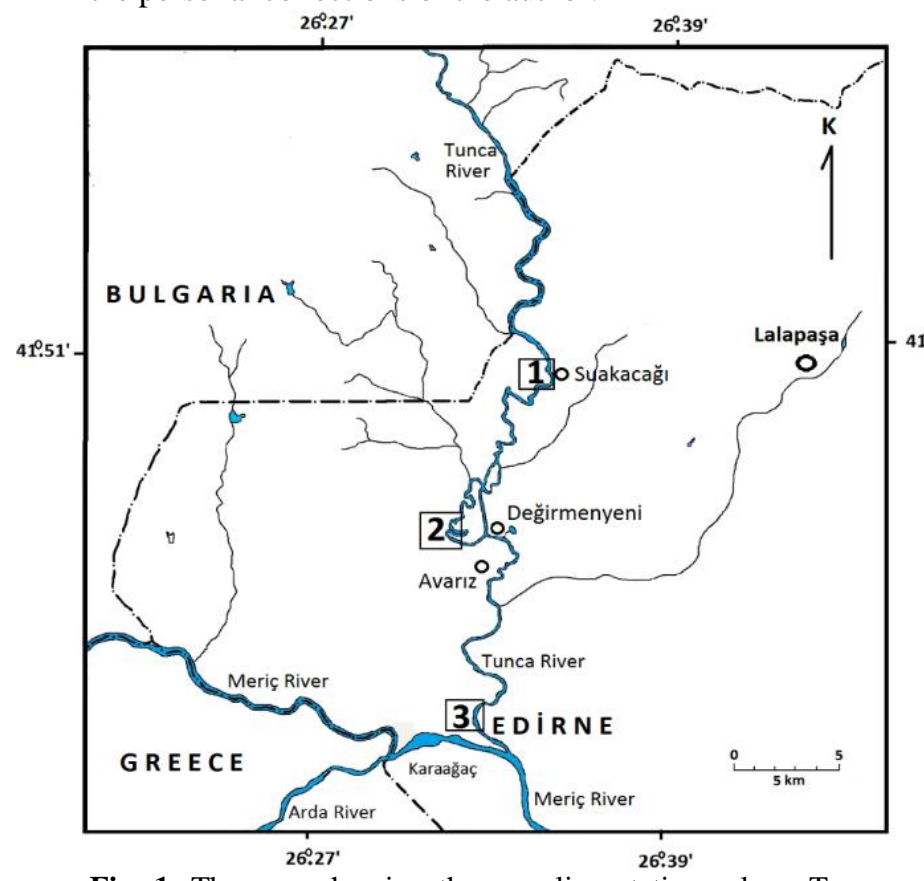

Fig. 1. The map showing the sampling stations along Tunca River. 1. Suakacağ 1 village $\left(46^{\circ} 54^{\prime} 09,00^{\prime \prime} \mathrm{E} ; 46^{\circ} 32^{\prime} 519,00^{\prime \prime} \mathrm{N}\right.$, $47 \mathrm{~m}$ a.s.1.), 2. Değirmenyeni village $\left(46^{\circ} 10^{\prime} 67,00^{\prime \prime} \mathrm{E}\right.$; $46^{\circ} 23^{\prime} 425,00^{\prime \prime} \mathrm{N}, \quad 40 \mathrm{~m}$ a.s.1.), 3. Edirne city center (46 $29^{\prime} 65,63^{\prime \prime} \mathrm{E} ; 46^{\circ} 19^{\prime} 414,88^{\prime \prime} \mathrm{N}, 37 \mathrm{~m}$ a.s.1.).

\section{Results and Discussion}

This present study reports $L$. moderata for the first time in Turkey. A total of $145 \mathrm{~L}$. moderata larvae were collected from sand, mud and vegetation. In Tunca River sampling zones, 11 larvae were found in the first station, 1 larvae in the second station and 133 larvae in the third station. The evaluation of distributions of the larvae in the stations considering the sampling months showed that August was the richest month for larval presence with 89 larvae, followed by July with 17 larvae, September with 16 larvae, October with 15 larvae and June with 7 larvae. 15 of these larvae were made into a permanent preparation.

\section{Description:}

\section{Lipiniella moderata Kalugina, 1970}

Head: Head capsule is wider compared to other Chironomini (Fig. 2 a).

Mentum: Mentum with median tooth comprising 4 small, subequal toothless, with 6 pairs of laterals, regularly decreasing in size. Ventromental plates contiguous medially, very narrow and $2 \mathrm{x}$ as wide as mentum, gently curved with fine continuous striate and dark longitudinal band becoming slenderer laterally. Setae submental simple (Fig. 2e, h).

Mandible: Mandible with a pale dorsal tooth and three moderately darker inner teeth. The dorsal tooth is shorter than the apical inner teeth. Seta subdentalis short, simple. Seta internal of 4 plumose branches. Pecten mandibularis comprising 10-15 long setae (Fig. 2f).

Labrum: SI seta coarsely plumose on both side, SII simple, SIII fine, simple, SIVa simple sensillum. Labral lamellae normal. Pecten epipharyngis long, apparently simple but actually finely divided into 3 parts, each with distal margin equipped with large and small teeth, without surface teeth (Fig. 2i). Premandible with 5 teeth, strong brush; seta premandibularis simple (Fig. 2d).

Antenna: The antennae are 5 jointed, and a big Ring organ (RO) exists at the bottom of the $1 / 3$ of the $1^{\text {st }}$ joint, seta absent, antennae breech extends to the middle of the $4^{\text {th }}$ joint and has an aiding antennae breech. There exist two opposite Lauterborn organs (LO) in the distal of the $2^{\text {nd }}$ joint as big and wide as the joint of the $3^{\text {rd }}$ antennal segment (Fig. 2c).

Body: L. moderata larvae are relatively large and lengths up to $11 \mathrm{~mm}$ and are light red in colour. At the end of the penultimate body segment there are two short and inflated ventral respiratory tubules (Fig 2b).

\section{Remarks:}

The larvae can be identified easily under a microscope. Members of Lipiniella have some common characters such as the shape of the mentum and ventromental plates, premandible with numerous teeth and pecten mandibularis with distally divided lamella (Paraskeva et al. 1992). L. moderata could easily be discriminated from the two-other species of the genus by the presence of ventral tubules on $11^{\text {th }}$ abdominal segment (Shilova et al. 1992). 

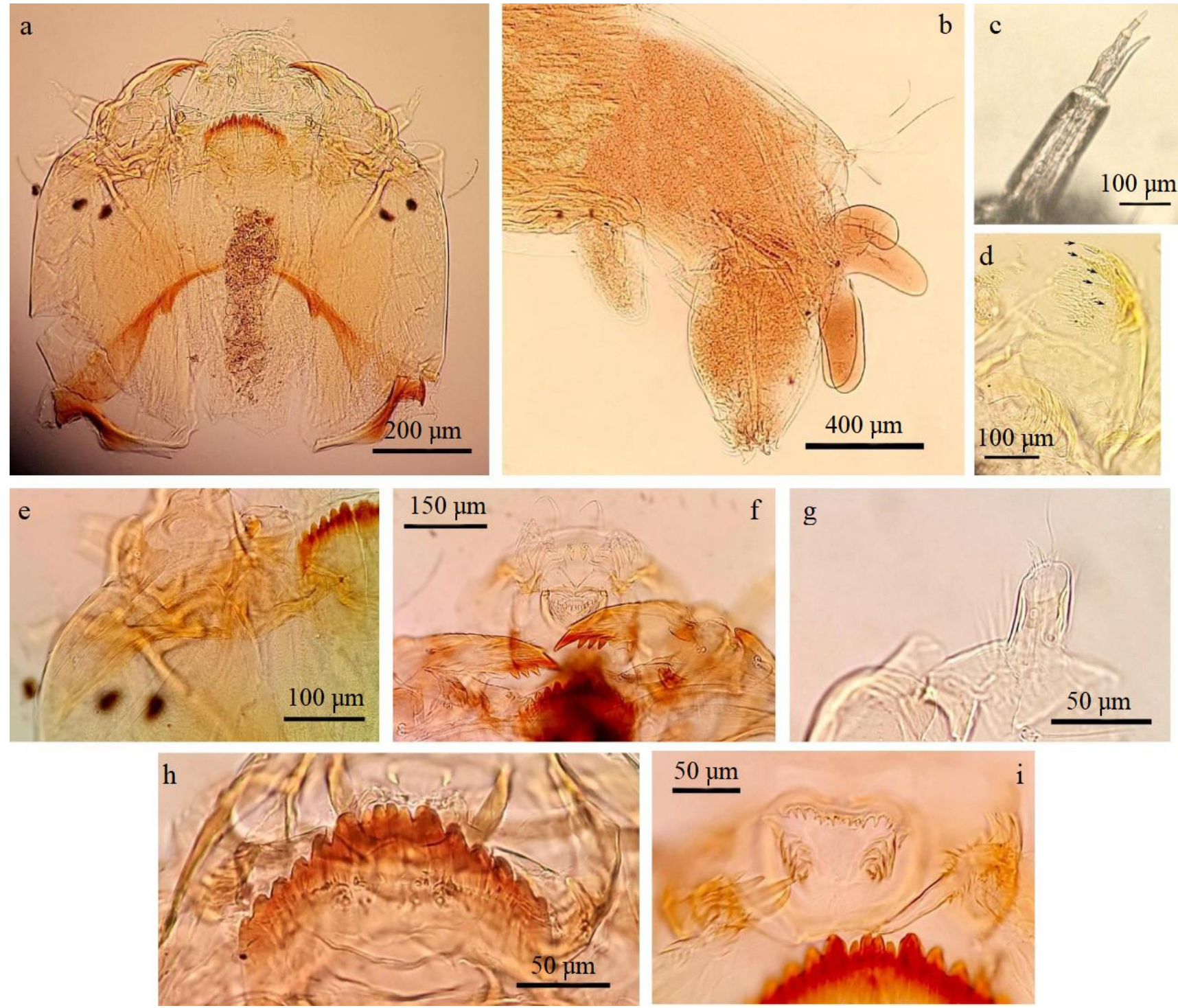

Fig. 2. Lipiniella moderata Kalugina, 1970. Ventral views of (except b) a) larval head capsule, b) last abdominal segments, c) antenna, d) premandible, e) mentum and ventromental plates, f) mandible, g) maxillary palp, h) mentum, and i) pecten epipharyngis, premandible.

\section{Community, habitat and ecology}

The macroinvertebrate community obtained with $L$. moderata included Potamothrix hammoniensis (Michaelsen, 1901), Limnodrilus hoffmeisteri Claparede, 1862, L. claparedeianus Ratzel, 1868 from Oligochaeta, Harnischia fuscimana (Kieffer, 1921), Polypedilum scalaenum (Schrank, 1803), P. nubeculosum (Meigen, 1804), P. exsectum (Kieffer, 1916), P. bicrenatum Kieffer, 1921, Microtendipes chloris (Meigen, 1818), Chironomus anthracinus Zetterstedt 1860, Procladius (Holotanypus) sp. from Chironomidae, Erpobdella octoculata (Linnaeus, 1758) from Hirudinea, Platycnemis pennipes (Pallas, 1771), Ischnura elegans (Van der Linden, 1820), Gomphus vulgatissimus (Linnaeus, 1758), Gomphus flavipes (Charpentier, 1825), Orthetrum albistylum (Selys, 1848) from Odonata, Potamantus luteus (Linne, 1767), (Burmeister, 1839), Caenis luctuosa Burmeister, 1838 (Ephemeroptera), Asellus aguaticus
(Linnaeus, 1758) from Isopoda, Ecnomus tenellus (Rambur, 1842), Cyrnus trimaculatus (Curtis, 1834) from Trichoptera) and Planorbella trivolvis (Say, 1817) from Gastropoda.

The $1^{\text {st }}$ and $2^{\text {nd }}$ sampling stations are characterized by mud, sand and vegetation while the $3^{\text {rd }}$ station is lacking the latter. The third station has a simpler appearance than the other stations in terms of trees, grass, and ground. The surrounding area is covered with grass. The population density of $L$. moderata was found to be quite high particularly in the 3rd sampling station in August. The fact that August is one of the hottest months has allowed the growth of plants and animals living in the water over time, and accordingly the breakup of the dead plants and animals. Under these conditions, the larvae may have increased their numbers by finding better nutrition. Population densities of $L$. moderata were reported to be low in Netherlands and Yugoslavia (Klink et al. 1995; 
Biró 2000), but Kiknadze et al. (1989) and Móra (2008) obtained the species in high numbers in Siberian waters (up to 100 larvae in the reservoir).

The features of the habitats from which the study material was sampled resemble to those reported by other researchers. The samples were found in large rivers in sand, vegetation and muddy habitats (Shilova et al. 1992, Moller Pillot 2009, Klukowska et al. 2011, Orendt \& Faasch 2011).

\section{References}

1. Ashe, P., Murray, D.A. \& Reiss, F. 1987. The zoogeographical distribution of Chironomidae (Insecta: Diptera). Annales de Limnologie, 23: 27-60.

2. Biró, K. 2000. Chironomidae (Insecta, Diptera, Chironomidae) from Hungary 2. new records of Lipiniella moderata Kalugina, 1970. Spixiana, 23: 175-158.

3. Bitušík, P., Hamerlík, L. \& Haviar, M. 2006. First records of chironomids (Diptera, Chironomidae) from Slovakia. Biologia, 61: 639-641.

4. Hamerlík, L. 2006. Faunistic records of Chironomidae (Diptera) from the Morava River, new for Czech Republic. Lauterbomia, 58: 79-81.

5. Kalugina, N.S. 1970. A new species of the genus Lipiniella (Diptera, Chironomidae). Zoologiceskij zurnal, 49: 10341038.

6. Kiknadze, I.I., Kerkis, I.E. Shilova, A.I. \& Filippova, M.A. 1989. A review of the species of the genus Lipiniella Shilova (Diptera), L. arenicola Shil. and L. moderata Kalug. Acta Biologica Debrecina Supplementum Oecologica Hungarica, 2: 115-128.

7. Klink, A., Mulder, J. Wilhelm, M. \& Jansen, M. 1995. Ecologische ontwikkelingen in de wateren van Blauwe Kamer 1989- 1995.- Hydrobiologisch Adviesburo Klink bv Wageningen. Rapporten en Mededelingen 58. In opdracht van Rijkswaterstaat Dir. Oost Nederland en Stichting Het Utrechts Landschap, Wageningen, 107 pp.

8. Klink, A.G. \& Moller Pillot, H.K.M. 2003. Chironomidae larvae. Key to the higher taxa and species of the lowlands of Northwestern Europe. World biodiversity database, CDROM Series. Expert Center for Taxonomic Identification, University of Amsterdam.

9. Klukowska, M., Płóciennik, M. \& Żbikowski. J. 2011. Lipiniella moderata (Diptera, Chironomidae) - new species for the Polish fauna. Lauterbornia, 72: 1-6.

10. Kobayashi, T., Nakazato, R. \& Higo, M. 2007. The identity of Japanese Lipiniella Shilova species (Diptera: Chironomidae). In: Contributions to the systematics and ecology of aquatic Diptera. Atribute to Ole A. Sæther. In: T. Andersen (ed.), the Caddis Press, Columbus, pp. 155164.

\section{Acknowledgement}

This study was supported financially by Trakya University Scientific Research Projects (TUBAP, project no: 2011/130). This work was presented as an oral presentation in the XI. European Conference on Social and Behavioral Sciences held in Rome, Italy on September 1-4, 2016 and its summary were published. The author thanks Assist. Prof. Dr. Gürçay Kıvanç Akyıldız in Pamukkale University, Turkey for his kind help in identification of the material.

11. Laville, H. \& Serratosio, B. 1996. Addition et correction à l'inventaire des chironomidés (Diptera, France) depuis 1990. Annales de Limnologie, 32:115-121.

12. Makarchenko, E.A. \& Makarchenko, M.A. 1999. Chironomidae. Non-biting midges.- In: Tsalolikhin, S. J. (ed.): Key to freshwater invertebrates of Russia and adjacent lands. Vol. 4. Higher Insects, Diptera, St. Peterburgh, pp. 210-295 and 670-857, (in Russian).

13. Moller Pillot, H.K.M. 2009. Chironomidae larvae. Biology and ecology of the Chironomini. (KNNV Publishing), Zeist, the Netherlands, 270 pp.

14. Morá, A. 2008. Faunistic particularities of the chironomid assemplages (Diptera: Chironomidae) of the Upper-Tisza, NE Hungary. Boletim do Museu Municipal do Funchal Suplemento, 13: 5-12.

15. Orendt, C. \& Spies, M. 2010. Bestimmungsschlüssel Chironomini: Illustrierter Bestimmungsschlüssel für die mitteleuropäischen Larven der Zuckmücken-Unterfamilien (Diptera: Chironomidae) sowie der Unterfamilie Chironominae, Tribus Chironomini. Unter Verwendung vorwiegend makroskopischer Merkmale, (Selbstverlag) Leipzig, 59 pp.

16. Orendt, C. \& Faasch, H. 2011. First record of Lipiniella moderata Kalugina, 1970 (Diptera, Chironomidae) from Germany. Lauterbornia, 72: 7-12.

17. Özkan, N. 2007. Larvae of Çanakkale region and their distribution. Trakya University Journal of Science, 8(2): 123-132.

18. Paraskeva, V.L., Michailova, L.C. \& Ferrington, J.R. 1992. The Karyotype of Axarus festivus (Say) and a comparison with species of Lipiniella (Chironomidae: Diptera). Netherlands Journal of Aquatic Ecology, 26(2-4): 181-185.

19. Sæther, O.A. \& Spies, M. 2011. Fauna Europaea: Chironomidae. In Beuk, P. \& Pape, T. (eds) Fauna Europaea: Diptera "Nematocera". Fauna Europaea version 2.4. http://www.faunaeur.org [accessed 3.2.2011].

20. Shilova, A.I., Kerkis, I.E. \& Kiknadze, I.I., 1992. Lipiniella prima sp. nov. (Diptera, Chironomidae), larva and karyotype. Netherlands Journal of Aquatic Ecology, 26: 197-201. 